\title{
AZ ÉLETEN ÁT TARTÓ TANULÁS \\ BIOLÓGIAI, PSZICHOLÓGIAI MEGHATÁROZÓI ÉS KORLÁTAI A PEDAGÓGUS HIVATÁS TÜKRÉBEN
}

\section{Pléh CSABa}

a Budapesti Müszaki Egyetem Kognitív Tudományi Tanszékének

egyetemi tanára

pleh@cogsci.bme.hu

Előadásomban két vízióból indulok ki az emberi életút hajlékonyságát és meghatározóit illetően. Ezt a két víziót az 1. táblázat mutatja.

1. táblázat: Két felfogás az ember hajlékonyságáról és életútjáról

\begin{tabular}{|l|l|}
\hline \multicolumn{1}{|c|}{ Nyitottság } & \multicolumn{1}{c|}{ Korlátok } \\
\hline $\begin{array}{l}\text { Az életen át való tanulás az emberi elme } \\
\text { újonságra való nyitottságától függ. }\end{array}$ & $\begin{array}{l}\text { Az emberi elme nem teljesen hajlékony, } \\
\text { számos korlátja van. }\end{array}$ \\
\hline $\begin{array}{l}\text { Elménk és agyunk egész életünkben } \\
\text { nyitva van. }\end{array}$ & $\begin{array}{l}\text { Az agy és az elme csak bizonyos életkorban } \\
\text { nyitottak. }\end{array}$ \\
\hline $\begin{array}{l}\text { Az életkor elörehaladtával különösen } \\
\text { jók vagyunk a tanulás stratégiai } \\
\text { megközelítésében és a kontrollban. }\end{array}$ & $\begin{array}{l}\text { Egyfolytában lassulunk és emlékeink } \\
\text { halványulnak. }\end{array}$ \\
\hline $\begin{array}{l}\text { Az új IKT forradalmi értékü mind } \\
\text { a tanulást, mind a tanítást megváltoztatja. }\end{array}$ & $\begin{array}{l}\text { Az új IKT felszínes feldolgozást képvisel } \\
\text { és a tartalmat felületes pásztázással váltja fel. }\end{array}$ \\
\hline
\end{tabular}

\section{Az utcai tanulás és a tanítás}

Általában úgy képzeljük el - a tudásalapú társadalom retorikája közepette is -, hogy a tanulás és a tudás elsajátítása intézményes keretek között történik, legfeljebb azon vitatkozunk, hogy ezek az intézmények és keretek úgymond poroszosak vagy kompetenciaalapúak legyenek-e. Érdemes azonban szem elött tartanunk azt, s ez érvényes filozófiai és tapasztalati pszichológiai szempontból is, hogy az ismeretelsajátítás és az ismeretszervezés két igen eltérő közegben él a modern világban. Ezt az eltérő közeget mutatja a 2. táblázat. 
2. táblázat: Az utcai ismeretelmélet és az intézményes tanulás viszonya

\begin{tabular}{|l|l|}
\hline \multicolumn{1}{|c|}{ Utcai tanulás } & \multicolumn{1}{c|}{ Iskolai tanulás } \\
\hline $\begin{array}{l}\text { Haszonelvü funkciók: tudni hogyan } \\
\text { és mire is jó. }\end{array}$ & $\begin{array}{l}\text { Kiválósági funkciók: tudni mit } \\
\text { és leképezni. }\end{array}$ \\
\hline Mintakövetés & Elvont tudás \\
\hline Horizontális és vertikális & Vertikális \\
\hline Készségalapú & Kijelentés elvü \\
\hline Csináló ember & Tudó ember \\
\hline
\end{tabular}

Tudásaikat és kompetenciáikat, ahogy Russel Hardin (2002) is elképzeli, az emberek nem mindig intézményes keretek között sajátítják el. Az intézményes keretek mellett fontos szerepet tölt be az utcai szintü tanulás, ahol - szemben az iskolai tanulás par excellence vertikális, azaz a tudás birtoklójától a nem birtoklójához történő vertikális átadás képével -, a tudásátadás egyszerre - egyenrangúak közötti horizontális, valamint vertikális. Sőt, ismerjük a tudásnak az inverz vertikális formáit is, amikor a gyerekek tanítanak meg bennünket valamire, például egy honlap használatára. Az iskolai és az utcai tudáselsajátítás viszonya a napjainkra vonatkozó nevelésszociológia izgalmas kérdéseit veti fel. Hogyan is változik meg a vertikális és horizontális ismeretszerzés korunkban, milyen lépésekben alakítja az IKT a horizontális átalakulást. A tudományos újdonságokban való tájékozódás életkori eltéréseire a University College London 2008-as vizsgálata kiválóan rámutat. ${ }^{1}$ A fiatalok nem mennek könyvtárba, hanem személyes és intézményes horizontális forrásokra támaszkodnak. Mint pszichológus nem fogok belekontárkodni ennek a részleteibe, inkább csak az elveket szeretném bemutatni. Az elvek sajátos módon kapcsolódnak ahhoz a kérdéshez is, hogy vajon az ember elsősorban kívülröl befelé irányuló átadási hatásokra alakul-e olyanná amilyen, vagy egy belső program kibontakozása során. A 3. táblázat mutatja ezeket a megközelítéseket, mint a centrifugális és centripetális emberkép kettősségét.

\footnotetext{
${ }^{1}$ http://www.ucl.ac.uk/infostudies/research/ciber/downloads/GG\%20Intute\%20Report.pdf
} 
3. táblázat: A tudás-kibontakozás két felfogása

\begin{tabular}{|l|l|}
\hline \multicolumn{1}{|c|}{ Centrifugális (kivü̈lröl indul) } & \multicolumn{1}{c|}{ Centripetális (belülröl indul) } \\
\hline Szocializáció & A vele született szerkezet kibontakozása \\
\hline Belsővé tétel & Gondolat-kifejezés \\
\hline Relativizmus & Egyetemesség \\
\hline A tanulási eszközök vezetnek. & Az eszközök a szolgák. \\
\hline Az intézmények alapvetően újító erejüek. & A tanítás-tanulás biológiai univerzáléi irányítanak. \\
\hline
\end{tabular}

E felfogások mentén vannak olyanok, akik - a legkülönbözőbb életkorokra vonatkoztatva - úgy képzelik el, hogy a tudásátadás lényegében megváltoztatja az ember biológiai vonásait, mások pedig úgy, hogy azokat legfeljebb modulálja. Michael Cole (2005), a kulturális pszichológia egyik vezetője fogalmazott meg élesen három lehetséges kapcsolatot a kulturális hatások és a biológiai vonások között, amit az 1. ábra mutat.

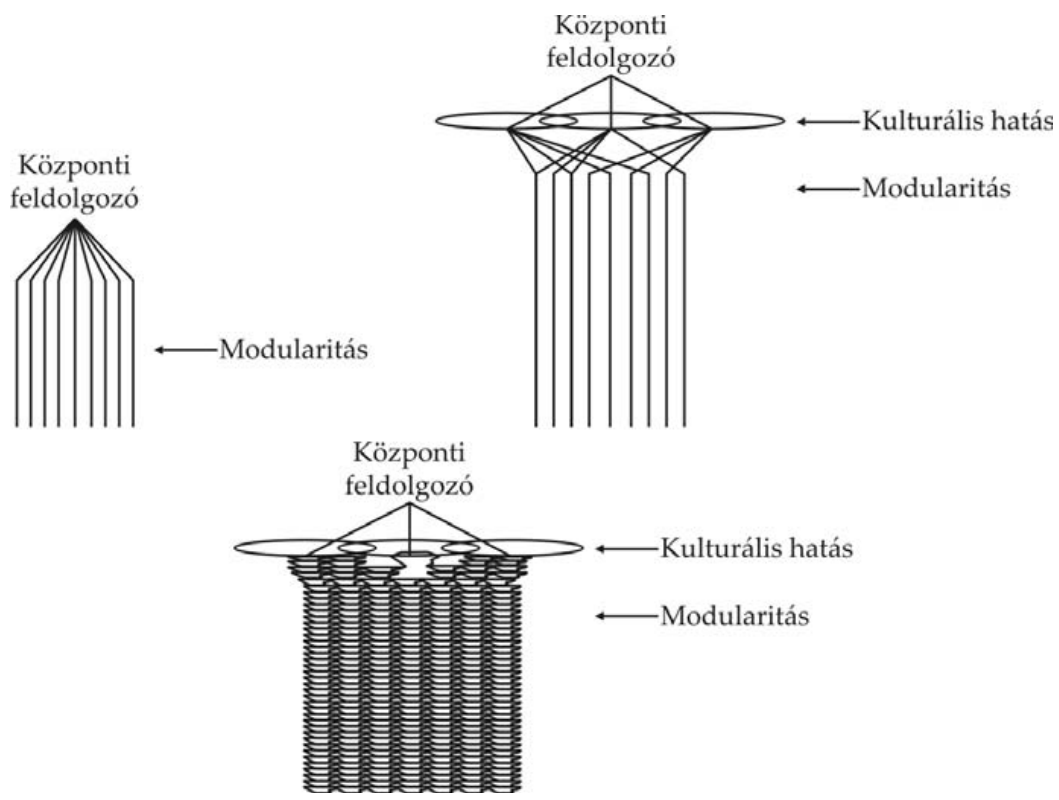

1. ábra: Az emberi gondolkodás építményének módosíthatóságának 3 felfogása $\left(\right.$ Cole, 2005) ${ }^{2}$

\footnotetext{
${ }^{2}$ A bal felső ábra a radikális rögzítettség, az alsó pedig a radikális módosíthatóság. A középutas felfogás szerint - jobbra fent - a kultúra az egységes gondolkodási integrációba beléptetve modulálja a biológiai megoldások eredményeit, de nem alakítja át azokat radikálisan.
} 
Az első felfogás, a radikális rögzitettség szerint, az embernek önmagában múködő, modulárisan szerveződő, biológiai eredetü, egyetemes megismerő és érzelmi rendszerei vannak, amelyek csak konvergenciaként alakítanak valamilyen közös tudatosítási felületet. Erre semmilyen értelemben nincs befolyása a kultúrának. A másik szélsőség, a radikális módosithatóság azt mondja, hogy a kulturális hatások felülről lefelé ható módon az ember biológiai feldolgozó rendszerét is megváltoztatják. Ha másképp tanuljuk a geometriát az iskolában, akkor másképp is fogjuk látni a tárgyakat. Ha több szó van a színekre, akkor másképp is fogjuk látni azokat stb. $A$ kompromisszumos, középutas felfogás szerint az embernek vannak automatikus és módosíthatatlan müködésű megismerési és érzésvilágbeli rendszerei. Ezeket a moduláris rendszereket kulturális behatás nem befolyásolja. Nagy mértékben befolyásolja azonban, hogy ezen rendszerek munkájának kimenetei hogyan kerülnek be a tudatba, a központi integráló és végrehajtó rendszerbe. A kultúra például, s maradjunk a színlátásnál, befolyásolja a rendelkezésre álló színcímkék révén, hogy miként fogunk emlékezni az észlelt színekre, de nem befolyásolja alapvető színrendszerünket. A könnyebben megjegyezhető színekre ugyanakkor jobban emlékszünk.

Mindez összekapcsolható a nevelésfilozófia olyan hagyományos kérdéseivel, hogy vajon az önmagában kibontakozó, vagy instrukciós alapú tanulási rendszerekben higgyünk-e. Gary Cziko (1995) fogalmazta meg igazából, hogy minden tudásváltozást el lehet képzelni szelekciós alapon. A tudásváltozásnak három különböző felfogása létezik a legkülönbözőbb területeken, az evolúcióban, a tanulás biológiájában, a pszichológiában és a nevelésben is (lásd 4. táblázat). A gondviselési felfogás mindentudó külső forrásokból indul ki. Az instrukciós felfogás az interakciók során érvényesülő külső okozásból indul, míg a szelekciós felfogás a próbálkozó szervezetet képzeli el, amely a próbálkozásainak eredményeiből tanul.

4. táblázat: Az ismeretváltozás különböző, lehetséges modelljei (Cziko, 1995 nyomán)

\begin{tabular}{|c|c|c|c|c|}
\hline Elmélettípus & Tudásforrás & Biológiai példa & Viselkedési példa & Nevelésfilozófia \\
\hline $\begin{array}{c}\text { Gondviselési } \\
\text { felfogás }\end{array}$ & $\begin{array}{c}\text { Mindentudó } \\
\text { külső forrás } \\
\text { (Isten) }\end{array}$ & Teremtés & $\begin{array}{c}\text { Velünk- } \\
\text { születettség }\end{array}$ & $\begin{array}{c}\text { Konzervatív } \\
\text { arisztokratizmus }\end{array}$ \\
\hline $\begin{array}{c}\text { Instrukciós } \\
\text { tudásforrás }\end{array}$ & Környezet & Lamarckizmus & $\begin{array}{c}\text { Kondicionálásos } \\
\text { tanulás }\end{array}$ & $\begin{array}{c}\text { Herbarti } \\
\text { empirizmus }\end{array}$ \\
\hline $\begin{array}{c}\text { Szelekciós } \\
\text { tudásforrás }\end{array}$ & $\begin{array}{c}\text { Visszajelzés } \\
\text { a próbákból }\end{array}$ & Darwinizmus & $\begin{array}{c}\text { Hibajavító } \\
\text { önfejlödés }\end{array}$ & $\begin{array}{c}\text { Pátyolgatott } \\
\text { kibontakozás }\end{array}$ \\
\hline
\end{tabular}

Természetesen a régi szociológiai felfogásban a megismerésre és a világra vonatkozó rend a káoszból teremtődik. Kiinduló állapotban csak káosz van, a tudást és a rendet mi visszük bele a világba. A szelekciós felfogásban viszont mindig hipotézi- 
sek vannak, ahogy Karl R. Popper $(1972,1998)$ megfogalmazta, és ezek a hipotézisek, amelyek már eleve rendet alkotnak, például biológiai rendet, egy új rendnek fognak helyt adni. Az instrukciós felfogás teljesen konstrukcionista, a szelekciós felfogás nem a semmiből konstruál mentális rendet, hanem a meglévő rendszerből.

A pedagógia lehetőségeit tekintve Cziko felfogása szerint fontos tudnunk azt, hogy a különböző tudásváltozási típusok között kiemelkedő jelentősége van az öszszegződő konstruktív szelekciós felfogásnak. Mint a 2. ábra mutatja, ez felelne meg valójában az intézményes tanulásnak, míg a nem konstruktív szelekciók, illetve a nem kumulatív szelekciók felelnének meg az utcai tanulásnak.

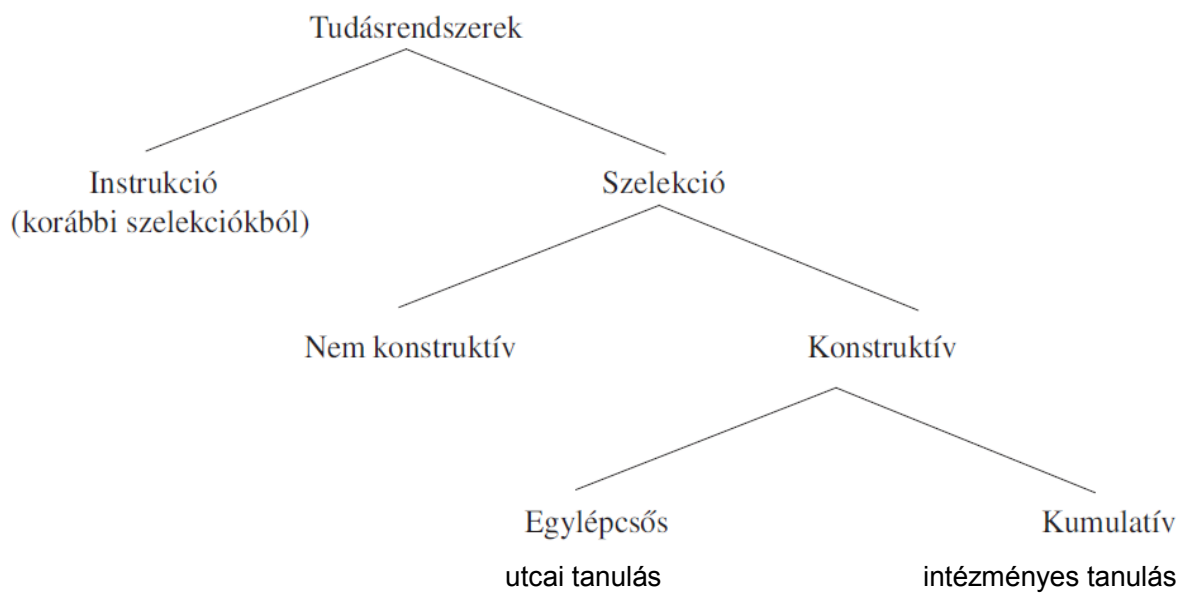

2. ábra: A szelekciós folyamatok hierarchiája és a nevelés Cziko (1995) felfogásában

\section{A tanítási-tanulási formák és az életkor}

Az életkorral természetesen megváltoznak a preferált elsajátítási és tudásváltozási formák, amelynek jellegzetes sorozata a mi, iskoláztatást használó kultúránkra a következőképpen vázolható.

Kisgyerek: Helyzetére jellemző a készségalapú „utcai ismeretszerzés”. Ez történik családi, játszótéri stb. közegben az intézményes nevelés kezdetei elött, ugyanakkor e keretekben is jellegzetes vertikális formák érvényesülnek. Az idősebb személy a tudás és a normák hordozója, s ezzel az átadást tekintélyhelyzet jellemzi.

Iskolai helyzetek: Öt-hat éves kortól a vertikális tudásátadás jellemző. Ez nemcsak a mai iskolákra jellemző, hanem a Rousseau-i ideálnak tekintett ősi társadalmakra is, amikor bizonyos készségeket a felnőtt nemzedék ad át a gyerekeknek. Madden, Bryson és Palimimi (2006) szerint az információátadás jelentős része ver- 
tikális az írástudatlan társadalmakban is, de míg a mi világunkban specialisták adják át a tudást, a törzsi társadalom felnőttjei ,generalisták”, kivéve a papi tudást.

Életen át tanulás: Az iskolából kikerülve, de ma egyre inkább az iskolai években is megjelenik a horizontális átvitelen alapuló készségformálás, a társaktól tanulás. Amikor egy orvos megtanulja a metszetek nézését a mestertől, amikor egy villanyszerelö megtanulja a forrasztást, amikor megtanuljuk egy adott honlap használatát, akkor nem idősebb tekintélytől s felkent specialistától tanulunk, hanem kortársaktól.

A mai pszichológia egyik nagy új felismerése ezen a területen az a feltételezés, hogy a kulturális átadás már a legkorábbi életkorokban is az emberben eleve meglévö biológiai rendszer. Ezt a felfogást először igen határozottan Michael Tomasello (2002, 2010) fogalmazta meg. Felfogásában a kulturális átadás lényege a hagyományos szociologizmussal és kulturalizmussal szemben az, hogy nem a kultúra hozza létre a sajátosan az emberre jellemző kulturális és tanulási formákat, hanem fordítva: az emberré válás során jön létre egy kulturális tanulási minta, $\mathrm{s}$ ez teszi lehetővé a kultúra létrejöttét. Az embernek van néhány olyan adaptációja, például a tekintet követése, vagy a társaktól való tanulás képessége, vagy az együttmüködés és összehangolás a feladatmegoldásban, melyek elvezetnek oda, hogy már gyermekkorunkban is olyan tanuló lények legyünk, mint amit a 3. ábra foglal öszsze. Közös célokkal, közös szándékrendszerben hajtunk végre a feladatokat és ebböl tanulunk.

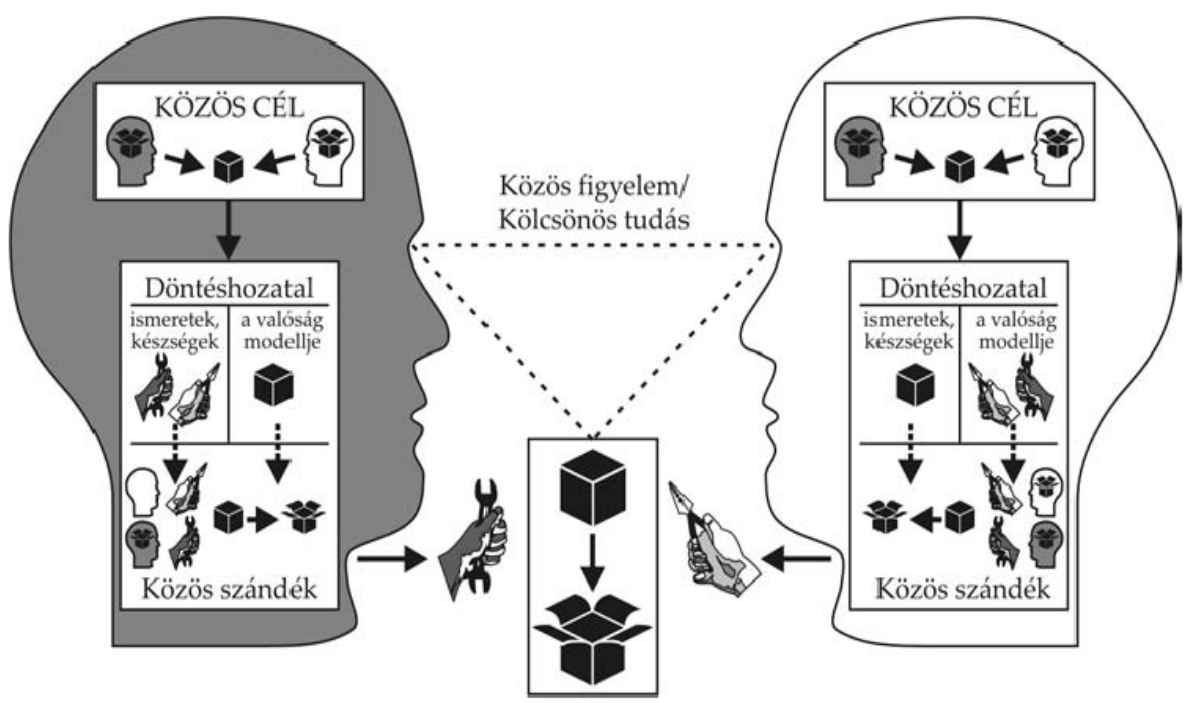

3. ábra: A kulturális tanulás és a közös intencionalitás Tomasello felfogásában 
Az utóbbi tíz évben két magyar kutató, Csibra Gergely és Gergely György (2007) ezt a felfogást kiterjesztették egy sajátos új keretbe, a természetes pedagógia keretébe. Az ő felfogásukban az emberré válás során három különböző elsajátítási mód különböztethetö meg:

1. szint: veleszületett genetikai viselkedésformák;

2. szint: környezetalapú tanulási mechanizmusok;

3. szint: a természetes pedagógia emberspecifikus biológiai alapú kulturális tanulási mechanizmusai.

Csibra és Gergely felfogásában már az egy év alatti csecsemők is képesek arra, hogy észrevegyék, hogy a környezet rámutató támpontokkal éppen valamire tanítja őket. Elvárt tanulási helyzetekben bontakoznak ki a világra vonatkozó általánosítások. A tanítási támpontok mellett már az egy év körüli baba is képes megtanulni, hogy például anyja arckifejezése nem a saját érzelmi állapotát tükrözi, hanem azt, hogy az a tárgy, amire néz, az rossz, „,büdös” és így tovább. Ezeket a tanitási helyzeteket a rámutató mozzanatok, például a szemkontaktus, már négy hónapos korban beállítják, s ezek lesznek képesek arra, hogy elindítsák a gyerekeket a kultúra önkényeinek rögös elsajátítási útján. A gyermeknek nem kell külön megtanulni azt, hogy a felnőtt által produkált furcsa, irracionális, „,nem következő” viselkedésekre figyelni kell. Erre mintegy a természetes pedagógia révén fel van készülve. Azt kell megtanulnia, hogy az ő kultúrájában éppen milyen rituálék, éppen milyen szavak, pontosan milyen önkényes jelzésrendszerek lesznek érvényesek.

\section{Az időzítés kérdése}

A 20. század közepétől a modern pszichológia öröklés- és környezet-típusú vitáinak egyik sajátos megoldásává válik az etológiából átvett kritikus vagy érzékeny periódusok fogalma (lásd Pléh, 2008b összefoglalását). Ennek kitüntetett eseteit a korai etológiában már 1930-ban Konrad Lorenz megfigyeléses módszerekkel leírta a fészekhagyó madaraknál. Azóta részletesen tisztáztuk, hogy a fajtársat követő viselkedésnek rendkívül különleges körülményei vannak. A kiscsirke vagy a kismadár a tojásból kikerülés után 12-36 órán belül képes követni minden olyan tárgyat, amely jellegzetes, ritmikus hangokat ad, vagyis már születéskor sajátos előkészítettséggel rendelkezik. Számos más fajnál, emlősöknél is feltárták a kritikus periódusok létezését. Ilyen például a korai környezetgazdagítás szerepe, a kézbevétel vagy a stressz-reakció. Azok a patkányok, amelyeket az elválasztást követő hetekben sokszor kézbe vesznek az emberek, sokkal gyorsabban fognak tanulni, sokkal kövérebbek lesznek, valószínüleg azért, mert sokkal korábban megérik és sokkal kevésbé lesz túlreagáló a vészhelyzet rendszerük.

Az emberszabásúaknál és az embereknél természetesen jellegzetes példája ennek a kötödés. Már az 1930-as évek elején Hermann Imre (új kiadás 1984), az 1940-es években René Spitz (Spitz és Wolf, 1946), az 1950-es évek elején Harry 
Harlow (1958), majd az 1960-as években John Bowlby (1969) pszichológiai és etológiai kölcsönös interpretációval igyekszik megmutatni, hogy a kötődésnek milyen óriási szerepe van. Bowlby elméletéhez kapcsolódóan azután különféle tipológiák jöttek létre. Fontos azonban emlékeznünk rá, hogy amikor az emberi kritikus periódusokról beszélünk, egész más időzítésekről van szó. Madaraknál 12-36 óráról, embereknél a kötődésben egy évről, a nyelvelsajátitásban öt-tíz évről beszélhetünk. S míg például a madaraknál vagy a rágcsálók ún. handling reakciójánál (a rendszeres emberi kézbevételre adott fejlődési gyorsulási reakció) világos, hogy mi az, ami lezárja a kritikus periódust, addig az ember szempontjából már sokkal nehezebb ez a kérdés. A 4. ábra mutat két jellegzetes példát erre vonatkozóan.

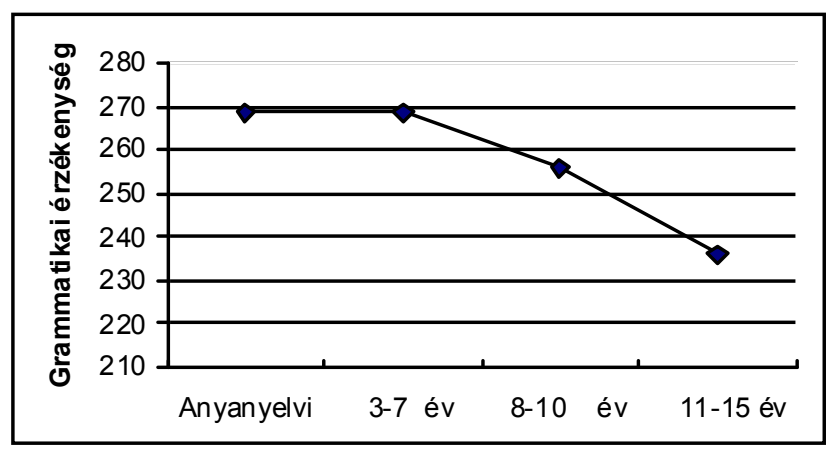

Newport (Newport, 1990) adatai a nyelvi fejlődés kritikus periódusáról. A prepubertástól már nem javul a teljesítmény.

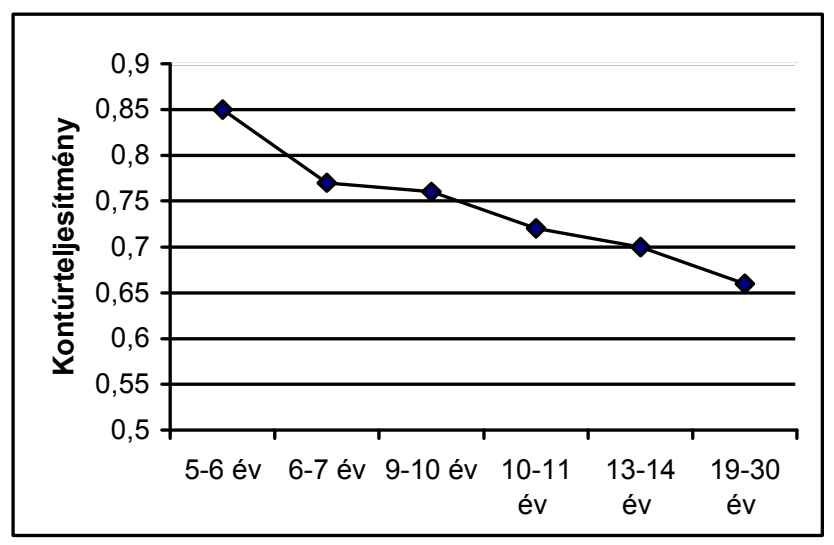

Kovács Ilona (2003) adatai a kontúrérzékenység fejlődésének kritikus periódusáról. 10-11 éves kor után lassul a változás.

4. ábra: Két jellegzetes kritikus periódus az embernél: a nyelv és a látási felbontó képesség fejlődése 
Látjuk jól, hogy mindkét esetben, valahol a serdülőkor megkezdésekor zárul le a kritikus periódus. A kritikus periódus általános tanulási jelentőségének megértésében fontos segítséget nyújt, ha megnézzük, hogy mit tudunk a kiterjedt emlőskísérletekböl. David Krech és Mark Rosenzweig (Rosenzweig et al., 1962; Rosenzweig, 1984) közel fél évszázadon keresztül vizsgálták patkányoknál a környezetgazdagítás hatását. A kutatóprogram csúcsa az 1960-as években volt, amikor az embergyerekeknél a Head Start oktatási program és hasonló korai fejlesztő programok keretei között megfogalmazódott, hogy miként lehetne állatkísérleti modelleket létrehozni a korai tapasztalás hatásainak vizsgálatára. Az 5. ábra mutatja, hogy milyen nagy hatással van a környezetgazdagítás a patkányok agyára.

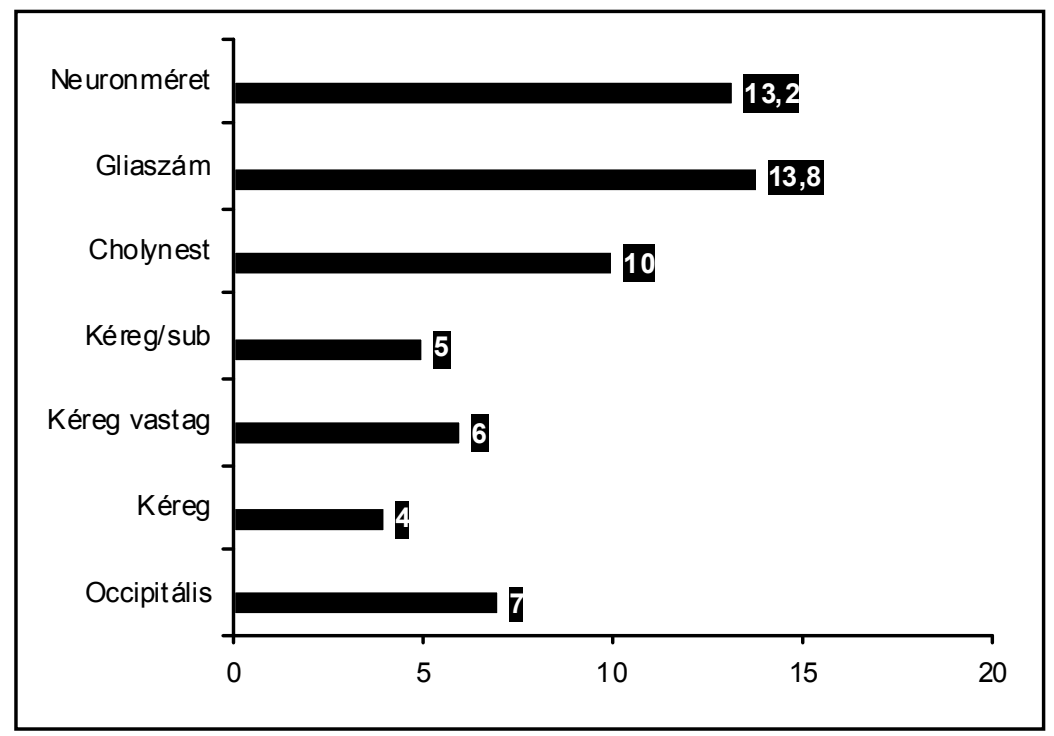

5. ábra: Korai tapasztalatok hatása a rágcsálók agyára, százalékos tapasztalati hatás (Rosenzweig és munkatársai nyomán, Pléh, 2008a alapján)

A klasszikus eredmények szerint, 25-105 napos kor között, a környezetgazdagítás morfológiai változásokat eredményez az agyban. Krech egyenesen azt mondja, hogy ez William Stern konvergencia-törvényének megfelelő hatásokat mutat, hiszen szelektív tenyésztéssel olyan állatokat is létre tud hozni, amelyeknél a hasonló gliaproliferáció, vagyis támasztószövet burjánzás, a kérgi vastagság-növekedés és a kolinerg, acethylcolin közvetítő anyagot használó aktivitás megnövekszik. Tehát az öröklött okosság és a tapasztalatok révén létrejövő okosság támadáspontja, ugyanaz a rendszer lenne (Rosenzweig, Krech és Bennett, 1961). 
Hasonló hatásokat embernél is kimutatnak. Jacobs, Schall és Scheibel (1993) a halántéklebeny Wernicke-területén, azon a területen, amelyet általában a szókincscsel kapcsolnak össze, post mortem elemzések alapján igen jelentős hatásokat mutatott ki a korai tapasztalással összefüggésben (lásd 6. ábra). Az iskolázás növeli a dendrit hosszúságát, vagyis a sejtek közötti kapcsolatok intenzívebbek lesznek. Ugyanez a bal oldalon érthetően nagyobb, mint a jobb oldalon, érdekes módon nőknél is, valószínüleg azért, mert a nők a kisebb agyméretüket mintegy „kompenzálják" ezzel a nagyobb kapcsolatsürüséggel. Van azonban egy rossz hír is: a felnőtt populációban -0,69-es korrelációt mutat ez a dendrit hosszúság az életkorral. Az életkor növekedésével gyengül lehetőségünk új idegrendszeri kapcsolatok létrehozására.

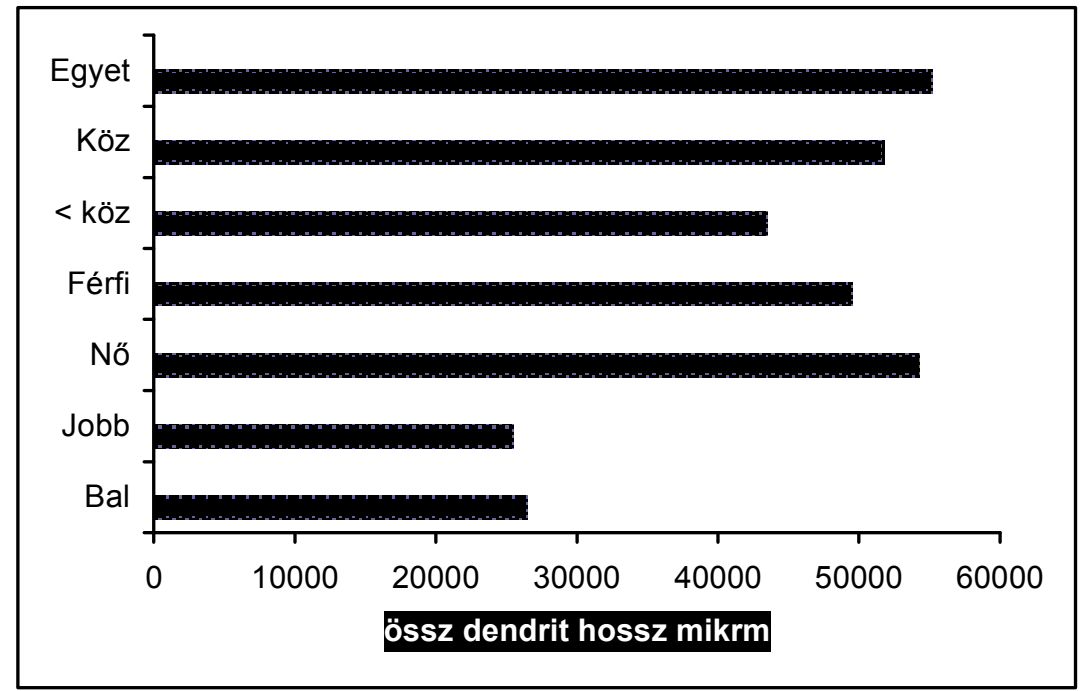

6. ábra: Tapasztalatok hatások az agyszövet hatékony használatára (Jacobs, Schall és Scheibel, 1993 nyomán)

Korai életkorban az idegrendszeri szinaptikus sürüség és a megfigyelhető teljesítménybeli változások között igen intenzív kapcsolat van. Mint a 7. ábra Peter $R$. Huttenlocher (2002) adatai alapján mutatja, a nyelv szempontjából legfontosabbnak tartott Broca- és Wernicke-területeken egyaránt három-négy éves kor között legnagyobb a szinaptikus sürüség. Ez az a kor, amikor megjelenik a szókincsrobbanás, és stabilizálódik a mondatszerkesztés elvrendszere, az anyanyelv alapvető grammatikája. 


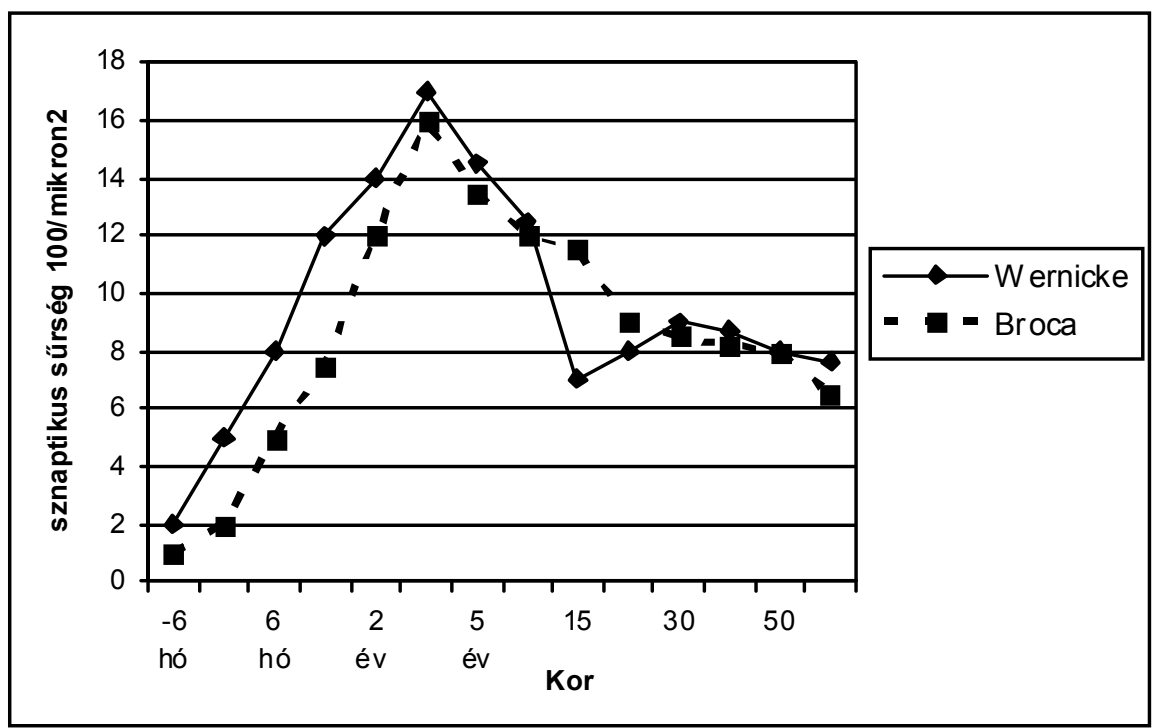

7. ábra: Életkor és szinaptikus sürüség két kulcsfontosságú agykérgi nyelvi területen Huttenlocher (2002) adatai alapján

Az utóbbi évtizedben igen érdekes új elképzelések fogalmazódtak meg az életkor, az idegrendszer és a kultúra viszonyának lehetséges felfogásáról. Stanilas Dehaene, a neurális alapú olvasáskutatás egyik legkiválóbb képviselője mutatott rá az utóbbi évtizedben arra, hogy úgy tünik - a szokványos felfogásoktól eltérően - a legkülönbözőbb írásrendszereket használó nyelvekben van egy terület a fali, a tarkó és a halántéklebeny találkozási pontjánál, mely az agyi képalkotó eljárások eredményei szerint mindig aktív, amikor olvasunk. Ezt a területet vizuális szóforma területnek nevezte el. Szerinte ez nyilván nem azért jött létre az evolúció során, hogy olvassunk, hanem a kislátószögü, vizuális felbontás céljaira. Az olvasás mintegy újracirkulálja, másodlagosan újrahasznosítja ezt a területet. A neurális újracirkulálás hipotézise szerint (Dehaene és Cohen, 2007) a következőkről van szó:

1. Az agyi szerveződésnek számos, erős anatómiai és kapcsolati korlátja van, amelyet az evolúcióban örököltünk. Csecsemökorban, igen korán megjelennek a jól szervezett neurális térképek, amelyek bizonyos irányba befolyásolják a későbbi tanulást.

2. A kulturális szerzeményeknek - például az olvasásnak - meg kell találniuk saját „,neurális fülkéjüket”, azaz olyan hálózati alhalmazt, amely elég közel áll a megkívánt müködéshez, és ugyanakkor elég hajlékony ahhoz, hogy idegrendszeri erőforrásainak jelentős részét az új használatba fektesse be. 
3. Amikor az evolúciósan régebbi funkciókra szánt agykérgi területeket megszállják az új kulturális tárgyak, e területek korábbi szerveződése nem teljesen iktatódik ki. Vagyis a korábbi neurális korlátok óriási hatást gyakorolnak a kulturális elsajátításra és a felnőttkori idegrendszeri szerveződésre.

Dehaene az elképzelését egy kései kulturális rendszerre, az írás rendszerére fogalmazta meg, s analógiával terjesztette ki a nyelvre. Anderson (2007) egy kiterjedtebb elemzésben egyenesen azt hirdeti, hogy minél újabb egy kognitív funkció, annál több s szétszórtabb területen képeződik le az agykéregben. A nyelv ebben az értelemben új funkció például az észleléshez képest. Ezt a mozzanatot sokan spekulatívan kiterjesztik a természetes nyelv keletkezésére is. Amint Merlin Donald (2001b) megfogalmazza, maga a nyelv kialakulása is felfogható úgy, mint egy jellegzetes újratoborzása bizonyos funkcióknak. Donald egyenesen azt mondja, hogy bizonyos értelemben a nyelv, mint az ember által kialakított külső kultúra, az idegrendszeri determinációtól való elmenekülés egy sajátos formája: „Csak félig tréfálkozom, mikor azt mondom, hogy az emberi evolúció újragondolható, mint a Nagy Hominid Menekülés az Idegrendszertől. Az emberszabású majmok s köztünk levő legfontosabb különbség a kultúra, pontosabban a szimbolikus kultúra, mely javarészt nem az agyi dobozon belül, hanem kívül van. A kultúra a kognitív tevékenységet számos agyban elosztja, s uralja tagjai gondolkodását." (Donald, 2001b, 149. o.)

Mindez azt is jelenti, hogy a kultúra nem újonnan, nem a semmiből próbál létrehozni egy feltételezett teljes plaszticitásnak megfelelö új területeket, hanem mintegy megtalálja a neki legmegfelelőbb területeket. Felhasználhatnánk erre az elképzelésre is, Conrad Waddington (1957) sokat idézett kanalizációs felfogását, melyet a 8. ábra mutat.

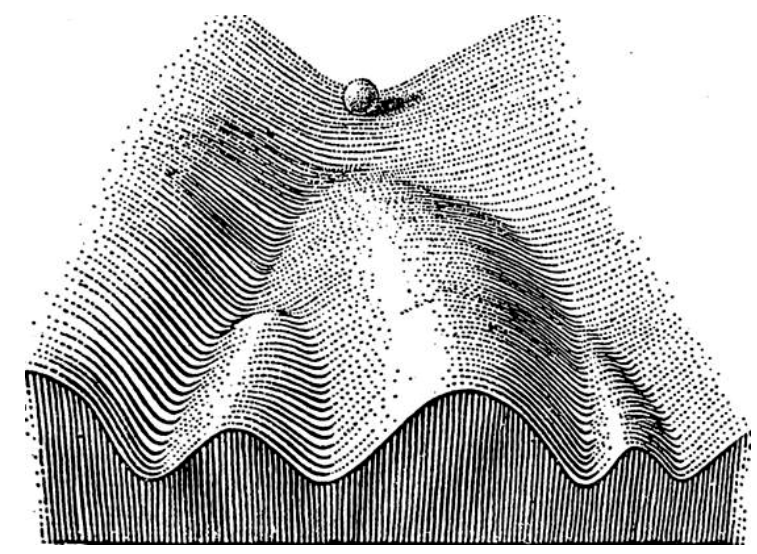

8. ábra: Conrad Waddington (1957) felfogása az evolúció és az egyéni fejlődési út viszonyáról 
Waddington ábrájában a golyó útja mutatja az egyéni életutat, míg a jellegzetes hullámvölgyek és dombok az evolúciósan kialakult, preferált tájképet. Ha ezt kiterjesztjük Dehaene kulturális újracirkulálási felfogására, úgy lehet elképzelnünk az iskolai tanulással alakítani és formálni kívánt nagy architekturális kulturális rendszereket, az írást, az olvasást, a számolást, mint amelyek az evolúciósan kialakult pályák optimalizációját szeretnék megtalálni az intézményes tanulás és tanítás körülményei között.

\section{A tanulási módszerek és az új információs technológia}

A mai kulturális és evolúciós pszichológia érintkezési területén több felfogás is megfogalmazódott arról, hogy milyen kapcsolat is lehetséges az átadási rendszerek és a tudásmegjelenítő rendszerek között. Ennek legjellegzetesebb példája Merlin Donald felfogása, melyet az 5. táblázat mutat.

5. táblázat: Merlin Donald (2001a) felfogása a nagy architekturális változásokról, kiegészítve néhány mozzanattal (Pléh, 2008a,b)

\begin{tabular}{|l|l|l|l|}
\hline \multicolumn{1}{|c|}{ A kultúra típusa } & \multicolumn{1}{|c|}{ Korszakok } & \multicolumn{1}{c|}{ Tudásközlés } & \multicolumn{1}{c|}{ Átadási mód } \\
\hline Epizodikus & Föemlösök, $5 \mathrm{~m}$ év & Eseményeken át & Nincsen \\
\hline Mimetikus & Erectus, $1,5 \mathrm{~m}$ év & Testtel & Lejátszás \\
\hline Mitikus & Sapiens, $50 \mathrm{e}$ év & Nyelvvel & Történet \\
\hline Teoretikus & Modern, 10 e év & Külső memória által & Írás-olvasás \\
\hline Gutenberg & Nyomtatás & Tömeges mém & Autoritás \\
\hline Hálózati & 10 év & Megosztott & Elektronika \\
\hline
\end{tabular}

A felfogás egyik legfontosabb felismerése, hogy nem kell feltétlenül ellentétet, hanem inkább folytonosságot lehet feltételezni a biológia és a kultúra között. A folytonosság lényege, hogy a közlési módszerek mindig a megjelenítési módszerek változását hozzák magukkal. Amikor például megjelenik sok ezer évvel ezelött az írás, ez az emlékezet új munkamegosztását hozza magával. Az írás megjelenésétől kezdve, saját emlékezeti rendszerünk nincs annyira megterhelve. Amikor előadást kell tartanunk például Vörösmarty szerelmi lírájáról, bemegyünk a könyvtárba, hogy megkeressük az erre vonatkozó irodalmakat, már ha egyáltalán tudtuk eredetileg, hogy ki volt Vörösmarty. A munkánkhoz azonban elég annyit tudnunk, hogy ki is volt ö, $\mathrm{s}$ akkor megtaláljuk a szükséges tudást.

Az így létrejövő új architektúrák egy másik jellemzője, hogy mintegy emulálják (másolják, utánozzák) a biológiát. Ennek jellegzetes példája, a Dehaene által is oly központinak tartott olvasás. A szavak olvasása, méghozzá a szemantikailag releváns olvasása, nagyságrendben ugyanannyi ideig tart, mint a tárgyak felismerése. 
Az olvasás ugyanolyan gyors, mint a tárgyfelismerési folyamat. A kérdés, hogy vajon a mai új közegben, az új IKT rendszerek megjelenésével végbemegy-e valamilyen hasonló forradalmi folyamat, mint amilyen az olvasás forradalma volt tízezer évvel ezelött és a Gutenberg forradalom néhány száz évvel ezelött. A hozzáférhetőségben nyilván óriási változások vannak. A 6. táblázat mutat ilyen óriási változásokat.

6. táblázat: A hagyományos és a mai tudásátadás néhány eltérése

\begin{tabular}{|l|l|}
\hline \multicolumn{1}{|c|}{ Hagyományos } & \multicolumn{1}{c|}{ Mai hálózat-alapú } \\
\hline Évtizedes tanulás & Kisebb az iskola szerepe \\
\hline Lassú hozzáférés & Gyors hozzáférés \\
\hline A tudás tulajdon & A tudás megosztott \\
\hline A bizonyosság kiküzdött vonás & A bizonyosságért még most küzdünk \\
\hline
\end{tabular}

Ebben az új világban a hozzáférés útjai nagyon jellegzetesen megváltoznak. A klasszikus világban az ember kénytelen volt elmenni az információ-tároló helyekre. Számtalan könyvtárba mentünk, a könyvtárakban fizikailag meg kellett fognunk a könyveket, s csak később, az utóbbi néhány évtizedben tudtuk egyáltalán lemásolni őket. A könyvből feljegyzéseket készítettünk, e feljegyzések alapján egy emlékezeti sémát alkottunk, majd ezekből vizsgáztunk, ezekből írtuk cikkeinket, egyszóval ezen a módon dolgoztuk fel az anyagot. A forrás, szinte Umberto Eco: A rózsa neve címü müvének megfelelően, különleges értéket képviselt. A mai világban az ember állandóan mozog, és egyre inkább arra törekszik, hogy az IKT révén minden tudáshoz állandóan hozzáférhessen. A fiatal nemzedék számára, ami nem digitalizált, az szinte nem is létezik, mint tudás. Hasonló ez, mint amikor az írásbeliség átvette a szóbeli kultúra helyét. Időben és térben is a teljes hozzáférhetöség és a teljes hozzáférés felé haladunk.

Mindez a mai pedagógia és társadalomfilozófia világában három felfogást alakított ki az új IKT és a kultúra viszonyáról.

1. Társas optimisták. Ezek szerint az új technológiák megváltoztatják gondolkodásmódunkat. Az állandóan bizonytalanul átalakuló szövegek világában posztmodernebbek leszünk, ahogy Nyiri Kristóf (1994, 2002; Nyíri és Szécsi, 1998) már évtizedekkel ezelőtt mondta, és ingadozóbbak, gyorsan változóak leszünk a könnyen letölthető, kis erőfeszítést igénylő szövegek közegében.

2. Társadalmi pesszimisták. Az új technológiák ellentmondanak az emberi természetnek. A konzervatív nevelésfilozófiának és társadalomfilozófiának megfelelően korlátoznunk kell az új technológiák használatát és a hozzájuk való hozzáférést. Új ludditák (új géprombolók) jelennek meg, 
akik a televíziót, de akár az internetet is kizárják, kizárnák az emberek világából. Nemcsak politikai okokból, mint az internet cenzúrázása a radikális, illetve konzervatív országokban, például Iránban vagy Kínában, hanem a mi modern európai világunkban is azért, hogy kényszerítsék az ifjú nemzedéket a hagyományos hozzáférési utak és feldolgozási módok használatára.

3. Biológiai optimisták. E felfogás képviselői szerint, az új technológiák sok mindent megváltoztatnak. A változások közepette azonban eredendő biológiai kereteink ismét uralkodni fognak. Az új technológiák nem szüntetik meg a régieket, hanem azokra építenek. Gondoljunk csak Donald modelljére! A hangzó nyelv megjelenése nem szüntette meg a gesztus-nyelvet vagy a mimikát, $\mathrm{s}$ az írás megjelenése sem szüntette meg a beszédet, hanem arra épített. Ugyanígy kell elképzelnünk a mai technológiák hatását.

A biológiai optimizmus jellegzetes képviselöje Robin Dunbar. Amint a 9. ábrán látjuk, Dunbar és munkatársa például kimutatja, hogy miközben úgy tünik, amolyan össze-vissza, zürzavaros hálózatok világában élünk, a hálózati kommunikáció világa ugyanúgy rekonstruálja eredendő, különböző intimitású kapcsolati világunkat, mint ahogy az a szemtöl-szembeni kommunikáció világában történik.

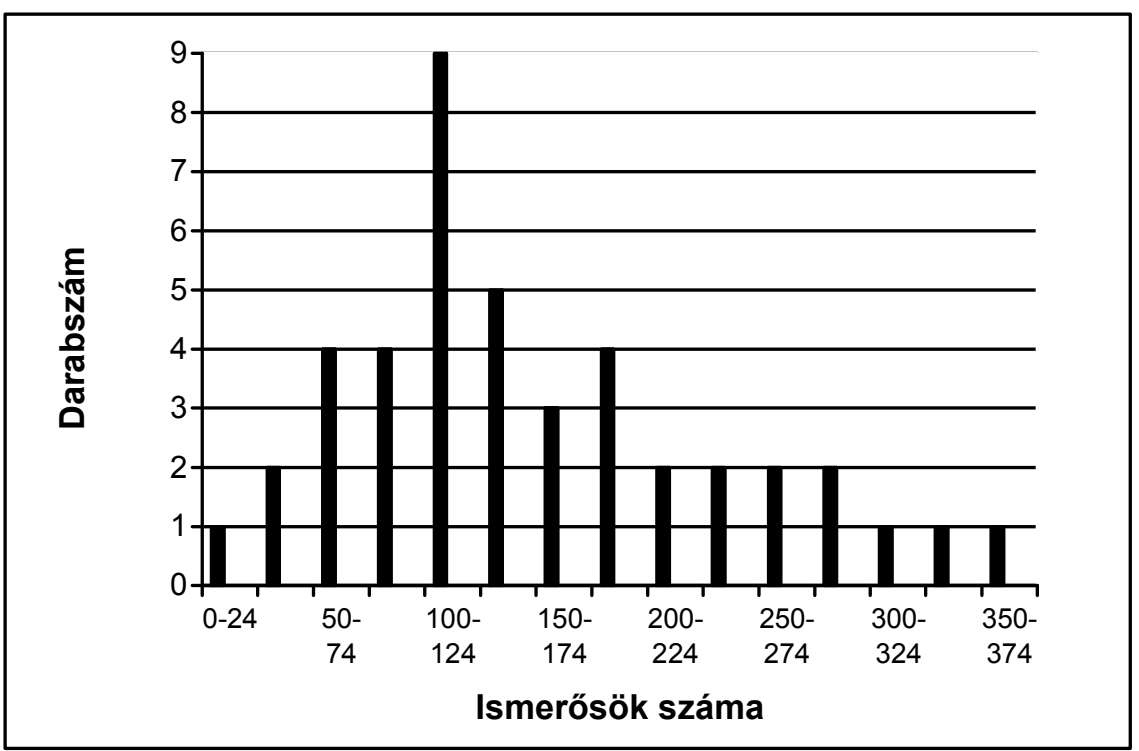

9. ábra: Maximális személyi háló. Hill és Dunbar (2003) adatai a modern IKT világában 
Hét-tíz olyan ember van, akikkel napi interakcióban vagyunk, 20-40, akikkel heti néhányszor kerülünk interakcióba, ám a külső hálózatunk sosem fogja meghaladni, a Dunbar szerint eredetileg mondott 140 fönél azért több, kb. 400 embert. Egész egyszerủen nem tudunk több kapcsolatot kezelni.

A modern nevelésfilozófiát elgondolkoztatja egy kiváló brit neurobiológus, Susan Greenfield kritikus véleménye. Greenfield szerint a hálózati típusú információszerzés kizárólagossága a fiatal nemzedékben azzal a veszéllyel fenyeget, hogy hozzászoknak a felszínes feldolgozáshoz, a tartalom helyett a folyamathoz. Nem a tartalomért olvasnak, a tartalom helyett a folyamatra helyezödik a hangsúly. Ezzel állandóan elköteleződünk az itt és a most világában, s eközben túl sok hangulatfokozó belső közvetítő anyagot, dopamint kapunk. Alacsony szinten müködnek a kontroll jellegü elülső homloklebenyi területeink és nem tudunk törődni a múltbeli és a jövőbeli mozzanatokkal. Az egyén elvész egy passzív állapot érdekében, és egy olyan passzív lény jön létre, aki a beérkező érzékletek áradatára reagál csak. A pillanatnyi élmények hangsúlyozódnak, ahol a személyesített agyi kapcsolatrendszer vagy teljesen megszünik, vagy legalábbis alacsony szinten funkcionál. Eltünik a testnyelv, a szemkontaktus, mindaz, amit mi oly fontosnak tartunk Csibra és Gergely (2007) nyomán is a természetes pedagógia keretében. Tehát megvan a veszély, hogy egy sajátos túlfutása jön létre az IKT alapú technológiáknak. Greenfield azonban azt gondolja, hogy van javitási lehetöség, mégpedig úgy, hogy olyan oktatástechnológiai eszközöket kell preferálnunk, amelyek elősegítik a lelassulást, valamint elösegítik, hogy újra tartalmas feldolgozás legyen, s ne szövegidézetek, hanem a sematizáció, vagy belső kivonatkészítés jellemezze az ifjúság NETes munkáját.

\section{Életkori változások felnőttkorban: jó és rossz hírek}

Az életen át való tanulás egész eszmeköre szempontjából nemcsak a gyermekkori kritikus periódusok az érdekesek, ti. ezekben a serdülőkornak sokkal nagyobb szerepe van, mint ahogy azt korábban gondoltuk. Serdülőkorban, mint Show (2006) és mások vizsgálatai rámutatnak, 12-16 éves kor között az utolsó nagy agyi változások lépnek fel. Ilyenkor mielinizálódnak a végrehajtó müködésekért felelős elülső homloklebenyi területek, és a serdülőkor az az idő, tudjuk jól a pedagógiából, amikor az erkölcsi tartás, az értékrend és az életcélok megfogalmazódnak. Olyan kor ez, amikor sokkal nagyobb felelősségünk van, mint azt korábban gondoltuk, amikor azt véltük, hogy minden az első három évben dől el. De nézzük tovább! Vannak későbbi évtizedek is! 


\section{Életkor, tapasztalás és kognitív változások}

A felnőtt világban az életkori változások egyik legtöbbet vitatott területe az emlékezet. Mindannyian tudjuk, hogy milyen nagy szerepet játszik hétköznapi életünkben a munkaemlékezet. Milyen fontos az, hogy hosszú számsorokat, helyek mintázatát és így tovább megjegyezzünk. Az egyik jellegzetes vizsgáló eszköze a számemlékezet, a másik jellegzetes vizsgáló módszere a Corsi-kockák ${ }^{3}$. A 10. ábra mutatja, hogyan is néznek ki ezek.

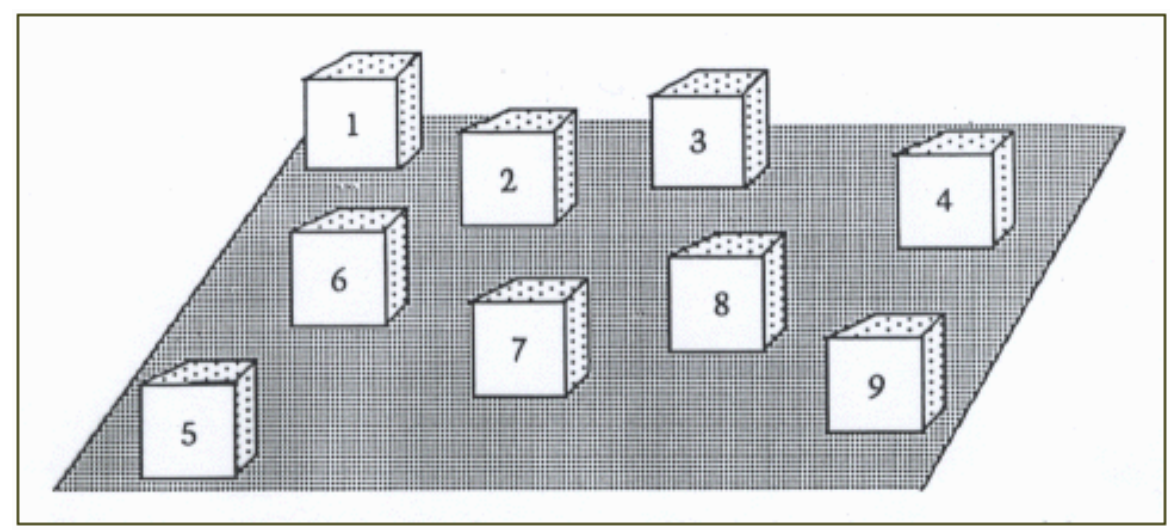

Számsorok: 2, 4, 5, 6; 8, 2, 1, 3, 4, 5, 9

10. ábra: Két jellegzetes feladathelyzet a munkaemlékezet vizuális és verbális összetevőinek vizsgálatára

Cavallini, Cornoldi és Vecchi (2009) igen alapos vizsgálataikban azt találták, hogy az életkor és a tevékenység egyaránt szerepet játszik ebben. Építészeknél egyáltalán nem meglepően, 30-70 éves kor között a vizuális emlékezet sokkal kevésbé csökken, mint a kontrollcsoportokban. Általában azonban a teljesítmény az életkorral drámaian gyengül. Ostrosky-Solis és Lozano (2006) sok tízezer ember vizsgálatát elemző kutatásaikban azt mutatták ki, hogy a legkülönbözöbb iskolázottságú személyeknél is megfigyelhetö 16 és 80 éves életkor között a számemlékezeti terjedelem csökkenése. Sőt, 80 éves életkorra, az eredetileg nagy szerepet játszó tanulási különbségek, mint azt a 11. ábra mutatja, eltünnek.

\footnotetext{
${ }^{3}$ A vizsgálatvezető által megérintett kockákat a vizsgálati személynek ismételten meg kell érintenie ugyanabban a sorrendben.
} 


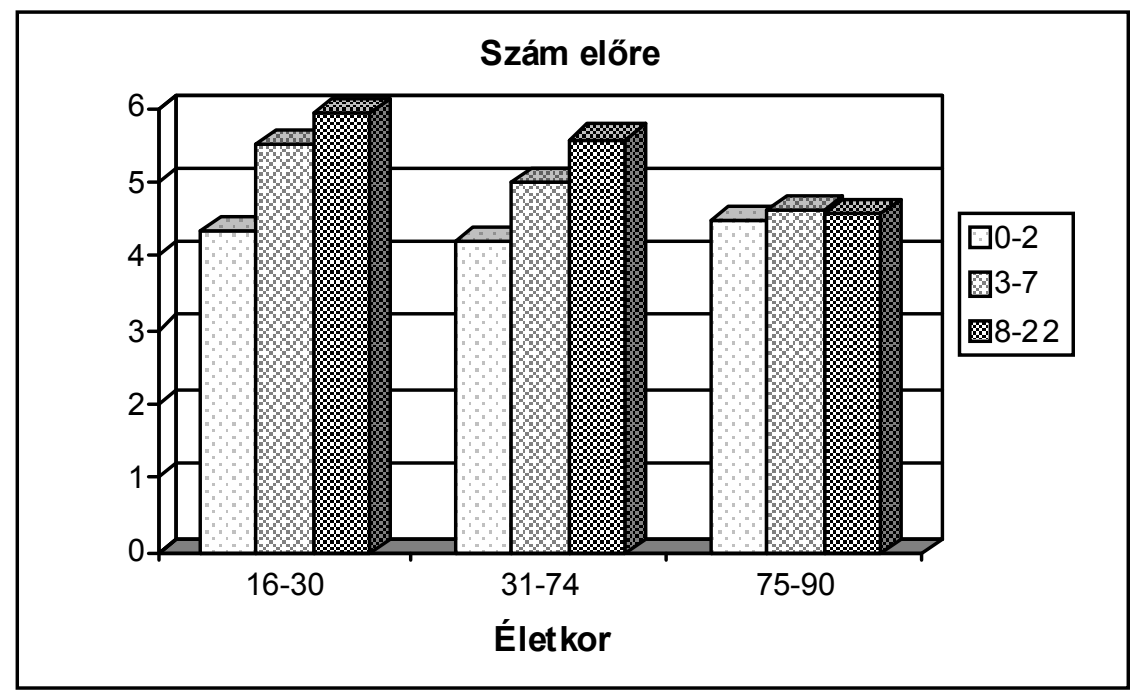

11. ábra: Az életkor és az iskolázottság hatása

a számemlékezeti feladatokra, az életkor és az iskolázottság függvénye

(Ostrosky-Solis és Lozano, 2006 nyomán)

Ugyanakkor, nagyon érdekes a visszafelé számolás emlékezeti teljesítménye. Ez a teljesítmény igazából a kontrollfunkciókat mutatja. Kontrollfunkcióban az iskolázatlan emberek már 16 éves korukban is sokkal gyengébb teljesítményt mutatnak, és érdekes módon, az életkorral nem megy végbe az iskolázottsági kiegyenlítődés. A visszafelé teljesítmény, a prefrontális területek tervezési, végrehajtó müködési szerepében sokkal élénkebben megmarad az iskolázottság hatása.

Mikels, Larkin és Reuter-Lorenz (2005) a sokféle életkori hatás mellett egy olyan izgalmas hatást is kimutattak, hogy az érettséggel az érzelmi érettség is megjelenik. Arra voltak kíváncsiak, hogy különböző ábráknál a személyek mennyire képesek megítélni egy közbeiktatott idő után, vagy egy semleges ábra után, hogy fenyegető vagy pozitív ábrát láttak-e. Mint a 12. ábra mutatja, az érzelem és az életkor között nagyon érdekes kölcsönhatást mutattak ki. Fiatal, 22 éves átlagéletkorú személyek a negatív érzelmekre sokkal jobban reagálnak, sokkal pontosabban, míg az idős személyek, akikről azt szoktuk gondolni, hogy sokkal negatívabb érzelmi beállítottságúak, sokkal pozitívabbak lesznek idős korukra. Úgy tünik, hogy az életkornak vannak pozitív és gondokat jelentő aspektusai is egymás mellett (lásd 7. táblázat). 


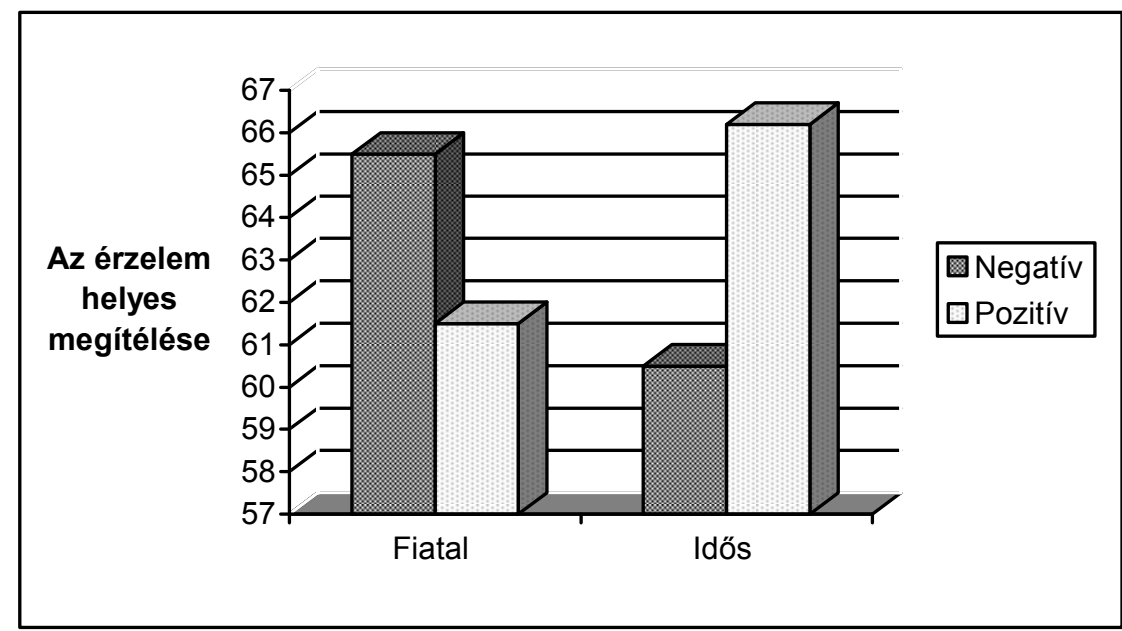

12. ábra: Két kép közötti érzelmi összhang megítélése különböző életkorokban (Mikels, Larkin és Reuter-Lorenz, 2005)

7. táblázat: Az életen át való tanulást befolyásoló pozitív és feszítő mozzanatok

\begin{tabular}{|l|l|}
\hline \multicolumn{1}{|c|}{ Pozitiv } & \multicolumn{1}{c|}{ Feszitö } \\
\hline Eröforrások jó kezelése & Lelassulás \\
\hline Korábbi mintákra építés & Funkcionális rögzülés \\
\hline Nagyobb válogatás & Érzéketlenség az újdonságra \\
\hline Bölcsesség & Túlzott óvatosság \\
\hline
\end{tabular}

\section{A tevékenység szerepe}

Az életkor szempontjából a mai pszichológiai kutatások, mint a 13. ábra mutatja, különbözö lehetséges pályákat mutatnak.

Mi minden befolyásolhatja, hogy melyik életpályát követjük? Az egyik, az intellektuális tevékenység. Bennett és munkatársai kiterjedt vizsgálatokban kimutatták, hogy minél több intellektuális tevékenységet folytat valaki, minél többet olvas, jár színházba vagy moziba, fejt keresztrejtvényt és így tovább, annál nagyobb az esély arra, hogy a patológiás emlékezetromlást kivédje. A szellemi tevékenység mellett azonban van egy másik befolyásoló tényező is. Colcombe és Kramer (2003) azt is kimutatták, hogy olyan feladathelyzetekben, amelyekben a személyek a keringési rendszerre különösen megterhelö, nehéz fizikai munkát végeznek, a fizikai tevékenység is sokat segít. Mint a 14. ábra mutatja, a fizikai tevékenység különösen segíti a nagy megterhelésü végrehajtó müködéseket. 


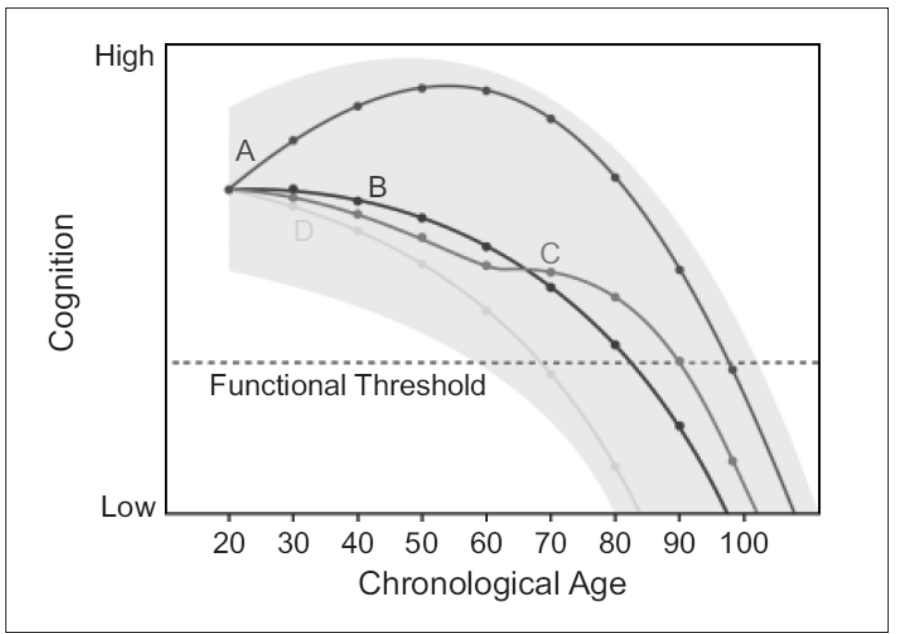

13. ábra: Különböző lehetséges pszichológiai müködési életpályák (Hertzog, 2008, nyomán)

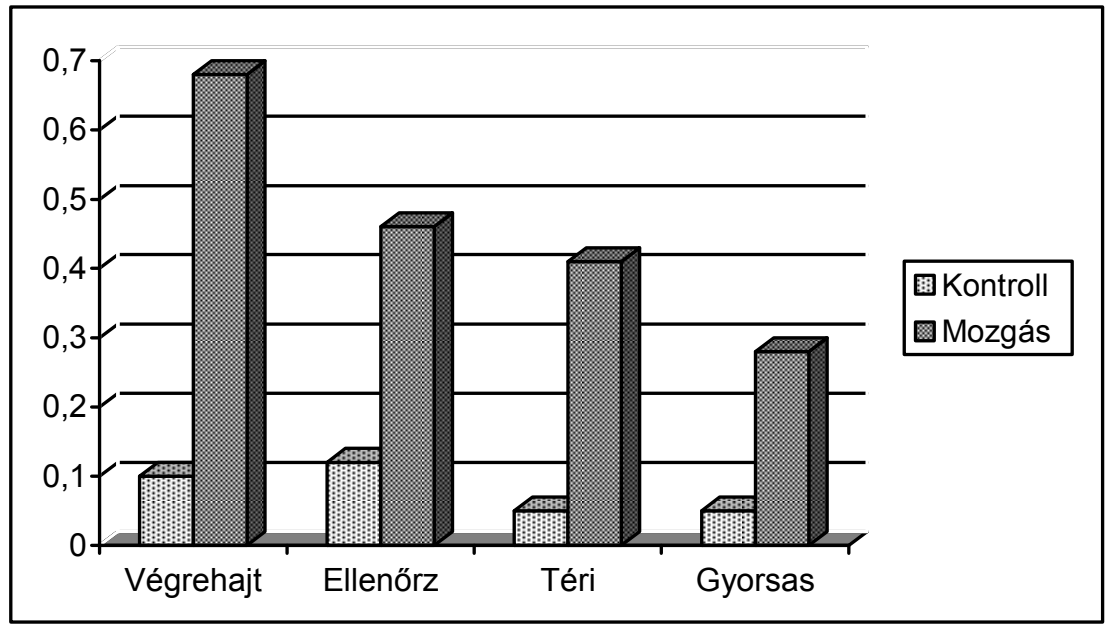

14. ábra: A mozgás és az erős fizikai tevékenység segíti az életkorral járó romlás kompenzálását (Colcombe és Kramer, 2003)

Mit mond mindez a tanári hivatás szempontjából? Az első mozzanat, ami az értékrendek kialakulásával kapcsolatos, hogy az elsődleges hivatásbeli szocializációnak korán érdemes megtörténnie. A középkorunktól kezdve pedig minden új tanulási helyzetben építenünk kell a horizontális átadásra és a meglévő tudásunkra, s nem 
szabad reménykednünk a gyors, radikális újításban. Az érettséggel a bölcsesség és az érzelmi érés, érettség új és új lehetőségei jelennek meg. Végül, mind a fizikai, mind a szellemi aktivitással kapcsolatos eredmények arra mutatnak, hogy frissességünk egyetlen kulcsa az állandó aktivitás.

\section{Irodalom}

Anderson, M. L. (2007): Evolution of cognitive function via redeployement of brain areas. The Neurosicientist, 13, 1-9.

Bowlby, J. (1969): Attachment and loss. Hoggarth Press, London.

Cavallini, E., Cornoldi, C., Vecchi, C. (2009): The effects of age and professional expertise on working memory performance. Applied Cognitive Psychology, 23, 382-395.

Colcombe, S., Kramer, A. F. (2003): Fitness Effects on the Cognitive Function of Older Adults: A Meta-Analytical Study. Psychological Science, 14, 125-130.

Cole, M. (2005): Kulturális pszichológia. Gondolat Kiadó, Budapest.

Cziko, G. (1995): Without miracles: Universal selection theory and the second Darwinian revolution. Mass. MIT Press, Cambridge.

Csibra Gergely, Gergely György (szerk., 2007): Ember és kultúra: A kulturális tudás eredete és átadásának mechanizmusai. Akadémiai Kiadó, Budapest.

Dehaene, S., Cohen, L. (2007): Cultural recycling of cortical maps. Neuron, 56, 384-398.

Donald, M. (2001a): Az emberi gondolkodás eredete. Osiris Kiadó, Budapest.

Donald, M. (2001b): A mind so rare. Norton, New York.

Hardin, R. (2002): Street-Level Epistemology and Political Participation. Journal of Political Philosophy, 10, 212-229.

Harlow, H. (1958): The nature of love. American Psychologist, 13, 573-685.

Hermann Imre (1984): Az ember ösi ösztönei. Magvető Kiadó, Budapest.

Hertzog, C. (2008): Enrichment effects on adult cognitive development: Can the functional capacity of older adults be preserved and enhanced? Psychological Sceince in the Public Interest, 9, 1-12.

Hill, R. A., Dunbar, R. (2003): Social network size in humans. Human Nature, 14, 53-72.

Huttenlocher, P. R. (2002): Neural plasticity. Harvard University Press, Cambridge, MA.

Jacobs, B., Schall, M., Scheibel, A. B. (1993): A quantitaive dendritic analysis of Wernicke's area. II. Gender, hemipspheric, and enviromental factors. Journal Comparative Neurology, 237, 97-111.

Kovács Ilona (2003): A látás fejlődése. In: Pléh Csaba, Gulyás Balázs, Kovács Gyula (szerk.): Kognitív Idegtudomány. Osiris Kiadó, Budapest, 273-284.

Madden, A. D., Bryson, J., Palimimi, J. (2006): Information Behavior in Pre-literate Societies. Information Science and Knowledge Management, 8, 33-53, DOI: 10.1007/14020-3670-1_3

Mikels, J. A., Larkin, G. R., Reuter-Lorenz, P. A. (2005): Divergent trajactories in the aging mind: Changes in working memory for affective versus visual information with age. Psychology and Aging, 20, 542-553. 
Newport, E. (1990): Maturational constraints on language learning. Cognitive Science, 14, $11-28$.

Nyíri J. Kristóf (1994): A hagyomány filozófiája. T-Twins Kiadó, Budapest.

Nyíri J. Kristóf (szerk., 2002): A XXI. század kommunikációja. MTA Filozófiai Kutatóintézet, Budapest.

Nyíri J. Kristóf, Szécsi Gábor (szerk., 1998): Szóbeliség és írásbeliség. Áron Kiadó, Budapest.

Ostrosky-Solis, F., Lozano, A. (2006): Digit span: effect of education and culture. International Journal of Psychology, 41, 333-341.

Pléh Csaba (2003): A természet és a lélek. Osiris Kiadó, Budapest. URL: http://www.tankonyvtar.hu/pszichologia/termeszet-lelek-pleh-080904

Pléh Csaba (2008a): A lélek és a lélektan örömei. Gondolat Kiadó, Budapest.

Pléh Csaba (2008b): A pszichológia örök témái. Typotex Kiadó, Budapest.

Polányi Mihály (1994): Személyes tudás. I-II. Atlantisz Könyvkiadó, Budapest.

Popper, K. (1972): Objective knowledge: An evolutionary approach. Clarendon Press, Oxford.

Popper, K. (1998): Test és elme: Az interakció védelmében. Typotex Kiadó, Budapest.

Rosenzweig, M. R. (1984): Experience, memory, and the brain. American Psychologist, 39, 365-76.

Rosenzweig, M. R, Krech D., Bennett E. L., Diamond M. C. (1962): Effects of environmental complexity and training on brain chemistry and anatomy: a replication and extension. Journal Comparative Physiological Psychology, 55, 429-437.

Rosenzweig, M. R. Krech, D., Bennett, E. L. (1961): Heredity, environment, brain biochemistry, and learning. In: Current trends in psychological theory. University of Pittsburgh Press, Pittssburgh. 87-110.

Ryle, G. (1974): A szellem fogalma. Gondolat Kiadó, Budapest.

Spitz, R. A., Wolf, K. M. (1946): Anaclitic depression: an inquiry into the genesis of psychiatric conditions in early childhood. II. Psychoanalytic Study of the Child, 2. 313342.

Tomasello, M. (2002): Gondolkodás és kultúra. Osiris Kiadó, Budapest.

Tomasello, M. (2010): Az együttmüködés eredete. Gondolat Kiadó, Budapest.

University College London (2008): Information Behaviour of the Researcher of the Future. URL: http://www.ucl.ac.uk/infostudies/research/ciber/downloads/GG\%20Intute\%20 Report.pdf

Waddington, C. H. (1957): The Strategy of the Genes. George Allen \& Unwin, London. 